\title{
Exploring the Dramatic Transition from the Deluge to COVID-19: The Case of Karen Malpede's Other Than We and Troy Too
}

\section{Khaled Saad Sirwah*}

\author{
ksirwah@art.kfs.edu.eg
}

\begin{abstract}
The present paper argues for a type of transition that has been dramatically made from the natural phenomenon of the "Deluge" to the global phenomenon of "COVID-19." Towards this end, the paper draws on an ecocritical approach with a view to tackling Karen Malpede's Other Than We (2019) and Troy Too (2020). The two texts are presented as a dramatic "Organon" that reveals how a fully-fledged environmental crisis has developed from the Deluge in the former play to COVID-19 in the latter due to man's transgression against nature. The paper has reached three findings. First, Malpede has moved thematically from the Deluge in $O T W$ to COVID-19 in TT by employing techniques such as language shifting, the anachronistic representation of Euripides' personae, poetry, and open ends. Second, the paper demonstrates how cultural ecofeminism surpassed radical ecofeminism in featuring women's roles not only in attempting a daring response to natural disasters but also in warning people against the gravity and immensity of pandemic diseases. Third, the playwright's vision has crystalized in an admonishingly prophetic light: We must act together in ways that will save, rather than destroy, us as well as all creatures on the planet.
\end{abstract}

Keywords: COVID-19, the Deluge, ecocriticism, ecofeminism, environment, Homo sapiens, nature, Newbies, plague, Troy

* An associate professor of English literature, Faculty of Arts, Kafreshikh University. 
Karen Malpede (1945- ), a co-founder of the Theater Three Collaborative in New York City, is an American playwright, writer, director, and professor whose work focuses on social justice issues. Teaching theatre and environmental justice at the John Jay College of Criminal Justice, Malpede is the editor of the well-known anthology, Women in Theater: Compassion and Hope (1984). She is described by Jody Strimling-Muchow as "a renegade artist" who has "dedicated her artistic talent to making a difference in the world" (para 1). She started writing plays with A Lament for Three Women (1979). Her famous plays include Prophecy (2008), a memory play about disturbed marriage marked by infidelities; Another Life (2011), a criticism of the American government's torture programme; and Extreme Whether (2014), a play about the struggle of scientists to tell the truth about climate change. Her most famous play is Other Than We (2019), a utopic-distopic cli-fi fantasy. Malpede's shortest and most recent play, Troy Too (2020), is about COVID-19, the climate crisis, and racism. The last two texts are directly concerned with climate change and its bad effects on humanity.

So far, there has not been a single study gathering Malpede's Other Than We and Troy Too under the umbrella of ecocriticism. The present paper seeks to see how the playwright has shifted thematically from the natural phenomenon of the "Deluge" in OTW to the global phenomenon of "COVID-19 in TT.

First coined by William Rueckert in 1978 (Mishra 168), ecocriticism, like many broad terms under which a variety of approaches fall, is difficult to define. While Lawrence Buell refers to it as an "increasingly heterogeneous movement" (1), Cheryll Glotfelty and Harold Fromm define it as "the study of the relationship between literature and the physical environment" (xviii). It has emerged in the 1980's as an "earth-centered approach" (Ibid xviii), including connections between environment and 
culture with the belief that the "human culture is connected to the physical world, affecting it and affected by it" (xix). Ecocriticism is, thus, interdisciplinary in the sense that it calls for collaboration between natural scientists, writers, literary critics, anthropologists, historians, and others. It incites scholars to examine themselves and the world around them, critiquing the way they represent, interact with, and construct the environment, whether natural or handmade. Joseph W. Meeker introduces the term "literary ecology" to refer to "the study of biological themes and relationships which appear in literary works. It is simultaneously an attempt to discover what roles have been played by literature in the ecology of the human species" (Qtd in Chandra and Das 10).

Ecocriticism redefines our relationship with the environment and literature. It has become a coherent and organized discipline within literary studies in the last decade of the $20^{\text {th }}$ century. It has emerged as a study of the relationship between literature and the natural environment in the mid-1990's. The goal of most ecocritical literature is to bring awareness to environmental problems and suggest possible solutions. Ecocriticism is an important step in bringing awareness to the environment problem the world faces today, but it only works if more people learn about it. Richard Kerridge argues:

The ecocritic wants to track environmental ideas and representations wherever they appear, to see more clearly a debate which seems to be taking place, often part-concealed, in a great many cultural spaces. Most of all, ecocriticism seeks to evaluate texts and ideas in terms of their coherence and usefulness as responses to environmental crisis.

(Qtd in Garrard 4)

Ecocritics have divided ecocriticism into two waves. Taking place throughout the 1980's and the 1990's, and characterized by its emphasis on nature writing as an object of study, the first wave 
stressed the environmental crisis of our age regarding it as the duty of both the humanities and the natural sciences to raise awareness and invent solutions to a problem that is both cultural and physical. This wave's concern was to "speak for" nature (Buell 11). This wave kept the cultural distinction between human and nature, promoting the value of nature. The second wave, breaking down some of the distinctions between the human and the non-human, nature and non-nature, discusses these boundaries as constructions challenged by ecocritics who ask how they frame the environmental crisis and its solution. This wave has redefined the term "environment" expanding its meaning to include both "nature" and the urban (Ibid). As a result of this expansion, a political branch of ecocriticism, the ecojustice movement, has grown to raise "an awareness of class, race, and gender through ecocritical reading of text" (Bressler 236). The two waves are not exactly distinct: while the first stresses that humans may have the ability to affect the environment negatively/positively, the second explores the deeper destruction on the environment that is mainly caused by human action.

Related to both environment and nature is the concept of ecofeminism - or ecological feminism - that can be regarded as a branch of ecocriticism and of feminism at the same time. Coined in 1974, ecofeminism examines the connections between women and nature. It "analyzes the interconnection of the oppression of women and nature" (Ibid). It alerts the attention to the fact that both women and nature are treated by patriarchal society in almost the same way. Ecofeminists examine the effect of gender categories in order to point out the ways in which social norms exercise unjust dominance over women and nature. "Drawing parallels between the domination of land and the domination of men over women, ecofeminists examine these hierarchical gendered relationships, in which the land is often equated with the feminine, seen as a fertile 
resource, and a property of man" (Shinde 111). Ecofeminism branches out into two schools: radical ecofeminism and cultural ecofeminism. Radical ecofeminism contends that the dominant patriarchal society equates nature and women in order to degrade both. This approach adopts the idea that women are inherently closer to nature biologically, spiritually and emotionally, and hence are set "against "culture, reason and the mind" (Garrard 24). Cultural ecofeminism, encouraging an association between women and the environment, contends that women have a more intimate relationship with nature because of their gender roles as family nurturer and provider of food and their biologymenstruation, pregnancy, and lactation. As a result, cultural ecofeminists believe that such associations allow women to be more sensitive to the sanctity and degradation of the environment. Moreover, they suggest that this sensitivity should be rewarded by society since it thus establishes a more direct connection to the natural world with which humans must coexist. Cultural ecofeminism also has roots in nature-based religions and goddess, and nature worship as a way of redeeming both the spirituality of nature and women's instrumental role in that spirituality (Miles para 6). Garrard concludes that "radical ecofeminism clearly functions as an inspiration to many to change their lives, but as a critical philosophy its irrationalism and essentialism are serious limitations" (27). As for Malpede as an ecofeminist playwright, she states:

It informs my work in every possible way. Ecofeminism is a way of being that is always aware of the importance of the earth and her many creatures, and the interconnectedness of all beings - the nonhierarchical relationship between healthy living systems. It's an assumption that the world is wrong-side out, that the 
relationship with self, with others, could be very different than it is. I try to show that in my work.

(Strimling-Muchow para 4)

However, if ecofeminism is part and parcel of ecocriticism, pandemic literature is closely associated with both. In dealing with plagues and epidemics from Homer's Iliad and Sophocles' Oedipus the King up till now, literature has a vital role in framing our responses to the COVID-19 pandemic. Iliad opens with a plague devastating the Greek camp at Troy to punish the Greeks for Agamemnon's enslavement of Chryseis. Like Iliad, Oedipus opens with an epidemic striking Thebes. Plagues are depicted as a divine retribution. Chelsea Haith argues: "Ranging from the classics to contemporary novels, pandemic literature offers something in the way of an uncertain comfort and a guide for what happens next" (para 3). In the $20^{\text {th }}$ century, Albert Camus' The Plague (1942) and Stephen King's The Stand (1974) brought readers' attentions to the social implications of plague-like pandemics-predominantly isolation and failures of the state to either contain the disease or moderate the ensuing panic. The self-isolation in Camus' novel creates an anxious awareness of the value of human contact and relationships in the citizens of the plague-stricken Algerian city of Oran (Haith para 11). In King's The Stand, a bioengineered superflu known as "Project Blue" leaks out of an American military base and chaos ensues. Haith comments that "King recently stated on Twitter that COVID-19 is certainly not as serious as his fictional pandemic, urging the public to take reasonable precautions" (Ibid). She argues: "Much of the literature on pandemics - the plague in particular-often describes the neglect, incompetence and selfishness of those in power" (Ibid para 5).

Pandemic literature is not always restricted to diseases; it includes other related themes such as class, race, and gender which 
are often mixed with social and political themes. Commenting on Bram Stoker's Dracula (1992), a critic argues:

The nature of disease and the fears related to infection can be tied to the social and political concerns of the period, illustrating that the fear of infection in Dracula mirrors not only the fear of national degeneracy in late Victorian England, but the dread of invasion as well. (Stock para 4)

This comment stresses that infectious diseases are always socially and politically related to their period. Jennifer Stock points out that Dracula has "come to England from a foreign land, bringing the metaphorical disease of vampirism which 'disturbs the relationship between the individual and God by defying death'" (Ibid). Similarly, in his novel Fever (2016), the African Deon Meyer dilates on the apocalyptic effect of a weaponised bioengineered virus resulting in enclaves of survivors besieging one another for resources. Moreover, in her satirical sci-fi novel Severance (2018), the Chinese American novelist Ling Ma provides a contemporary take on the zombie novel as the fictional "Shen Fever" renders people repetitive automatons until their deaths. In a thinly veiled metaphor for the capitalist cog-in-the-machine, the protagonist Candace drifts daily in to her place of work in a future New York that is slowly falling apart. She eventually joins a survival group, assimilating culturally and morally to their violent attitudes towards the zombies, "embodying the atomisation of late-capitalist humans in a society stripped to its bones" (Fan para 12). Stock strongly argues: "Zombiism is treated by authors and filmmakers as a pandemic and many critics tackling zombie stories focus on the theme of capitalism" (para 5). This implies that pandemics are related to capitalistic industries. According to Sven Cvek, "The zombie metaphor allows Whitehead to speak of the increasing economic and social insecurity of the American middle-class" (Ibid). 
Given the foregoing theoretical framework based on an ecocritical approach, the present paper seeks to answer one pivotal question: How could the interface between Other Than We and Troy Too conduce to the dramatic transition from the Deluge to COVID-19? This question entails a number of secondary queries: (1) What are the theatrical techniques employed by Malpede to move thematically from the Deluge in the cli-fi $O T W$ to COVID19 in the slice-of-life TT? (2) In what way does the ecocritical approach methodologically establish the transitional network between environmental and human elements in the two plays? (3) What is the dramatic vision proposed by Malpede in delineating the future complications of COVID-19 as an environmental crisis on the global scale?

A quick reading of Other Than We and Troy Too uncovers the thematic connection between them. Attempting a solution to such environmental crises as the Deluge by having new powerful creatures, the former paves the way for more disastrous pandemics such as COVID-19 in the latter.

Malpede's Other Than We (2019), a cli-fi fantasy falling in three parts and comprising twenty-four scenes, takes "place inside [and outside] the Dome, a hermetically sealed environment where the privileged remnants of society" live (2). It revolves around four characters, Michelle, Eve, Opa, and Tenaka. The first three, who "are among the privileged few who along with some refugees [like Tenaka] that work for them, have survived a cataclysmic 'Deluge' and occupy 'The Dome,' the only livable space on the planet" (Rosenthal para 2). The "Deluge" can be regarded as an environmental calamity the characters of the play have successfully survived and are trying hard to evade in the future. Michelle/Mick, "an obstetrician-gynecologist," and Eve, "a neuroscientist," who work as a part-time lecturer" (2), are encased in a movable cube constructed of scaffolding stage centre. They think of a new 
generation that will be stronger and more able to survive today's life. They have a radical plan or a utopian vision for a reconfigured race that will be "other than we," by serving as incubators or birthers through the help of Tenaka, "a refugee, formerly a physician" (2) and Opa, "a renowned public intellectual (based on Noam Chomsky), a linguist and grandfather of Eve" (2). Tenaka is one of those Africans who survived the Deluge.

The Deluge represents the environmental crisis Other Than $W e$ is obsessed with finding solutions to. The African Tenaka, in a flashback, expatiates on how his family suffered in the Deluge he survived. He saw his family sweeping "away in the Deluge, after the rains, in the winds, the floods, the water rushed" (51). He narrates how a little girl with the "blackest eyes in the world" and his wife with their "smiling baby" "were gone," while he could not swim seeing "the water like a wall, a force [he] had never seen before." "Many have seen what [he] did" and "many have lost everything" (51). He continues:

On the road, walking inland, walking up hill, staggering away from the sea, a woman, battered by branches, cut and scarred, sea weed stuck in her hair, asked if I might carry her child. She had a baby in her arms and she felt she could not go on. She wished to pass the child to me. Maybe I could carry it somewhere. I was walking. I was strong enough. I passed her. I acted as if I had not heard. Perhaps, she had not said anything at all. Perhaps, she had only looked and I saw as I used to see with my wife without words what was needed. I walked faster, as fast as I could walk, I walked away from her. I believe she sat down with her child to die as I walked past.

The above-quoted lines reveal how catastrophic and devastating the Deluge many people including Tenaka's own family have suffered and fallen victims to was! Had he not been "strong enough" he 
could not have survived. Tenaka explains how he, instead of helping a woman appealing to him for saving her child, "passed her [and] acted as if [he] had not heard" her. He "walked faster" (52), as fast as he could to survive. Commenting on how deluges are disastrous especially for the poor, Malpede says:

There have been a number of deluges recently. This past September, 11 people drowned in a deluge in New York City, Hurricane Ida. They lived in basement apartments with no windows and only one way out. The water washed in and drowned them. This is one example of a number of deluges around the world this year as the climate crisis intensifies. Always, we see it is the poor who suffer more. The wealthy do not live in basements.

("Facebook Message to Sirwah," 8 Nov. 2021)

Tenaka demonstrates in detail how ordinary people, "Homo sapiens," are no longer good for anything. They "became narrowminded and selfish [thinking] only of their own selves. They became limited in their compassion" (52). Out of his own experience, he admits that he walked and kept on walking saving only himself. He adds: "We cannot think ahead; we cannot stop ourselves from grasping. We are afraid of death; we walk away, we walk past the suffering of those not us. The suffering of others does not touch us as long as we walk. [...] I walked on and on" (52). This hard experience made him understand that

there will come a different moment, a turning, in years, perhaps sooner than we dare to wish, when life reasserts itself, and there will come a new, a noble race, of creatures who are capable of living fully, who want the best for others, who understand themselves as a part of, not apart from, who neither fear nor despise, who recognize, who bear their lives gladly, willingly, with restraint, and with 
joy welling up and they will be happy and fearless, careful, generous and kind.

Tenaka's words have found agreement on the part of Eve, who admits: "Tenaka, yes. I believe that, too. I do" (52). He is avid to have a new noble race of creatures who not only will be capable of living fully but also "would not think only of themselves. Would not live in fear" (52). Thus, the motive for both Tenaka and Eve to have a new nobler race is strong enough.

Malpede's play, in Eleanor Bader's words, "represents a post-apocalyptic scenario in which survivors have a chance to remark the world" (para 1). Michelle and Eve try to generate new creatures in their wombs by the help of Tenaka, who sneaks vials of multispecies sperm to them: "They implant eggs into [their] wombs" (3). The new creatures are called "Newbies," "humananimal creations of Eve, Mick and Tanaka, engineered to be able to survive in the harsh, new world - and to avoid the mistakes of Homo sapiens" (1). The Newbies are expected to replace Homo sapiens, who are not strong enough to survive today's harsh life. Michelle and Eve become noticeably pregnant and start to feel reluctant to it. Eve is so "increasingly hysterical" (19) that she admits:

I don't want my body like this. To be in this way. Belching, farting, full of gas. I don't want to be used by, invaded, a mother, what a stupid, insane, ridiculous, cruel thought, me. I never had a, I hated my, how could I, now I'm trapped, not myself, I am not, don't exist [sic]. Like Eve, Michelle says: "I will do an abortion" (19). They abhor their pregnancy because they are worried about their appearance. However, what makes them endure is their hope as birthers to give birth to a powerful generation. Both Eve and Michelle are reminiscent of Freya, who wanted to abort herself in Mike Bartlett's Earthquakes in London (2010). The difference between Freya and 
both Eve and Mick, as belonging to two generations, is the same as between the two schools of ecofeminism-radical and cultural ecofeminism. Unlike both Eve and Michelle who pay attention to their appearance, Freya has not paid any attention to her appearance and has been thus, like land and nature, weakened and victimized by the dominant patriarchal society.

Life is different inside the Dome selected by them as a place for the elite who have survived the Deluge. Opa regards that "Life inside the Dome is increasingly untenable." The food contains more lethal elements, the aquifer upon which the Dome was built has all but run out. [...] Purification of the same air likewise is no longer sustainable. Life inside the Dome for the privileged few is likely to cease far before..." (27). Thus, they have to seek more healthy foods with higher vitamins free from radiation to have more powerful generations. Michelle, "barefoot, with a basket; outside in a bleak landscape but with some vegetation," mentions elements such as asparagus, purslane and mushrooms in their many varieties - chanterelle, porcine, bolete, morels - argues that "There is natural radiation in fungi; it will build their resistance" (28). Moreover, she argues: "We'll have muggwort and peppermint for tea; they act medicinally. Nettles, watercress, scape, arugula, dandelion leaves. A salad, just think" (29). Both Eve and Mick are not only obsessed with their appearance as powerful women given voice for their hopes in giving birth to a powerful race but also aware of their gender roles as family nurturer and provider of food and their biology - menstruation, pregnancy, and lactation. All this classifies them into cultural ecofeminism since they thus have a more intimate relationship with nature. In addition to mentioning milk, butter, and eggs as very much needed, Michelle sees "asparagus stalks" as inevitable to be put into her vagina: "Tenaka, take these two stalks. Put them into my vagina" and repeats: "Take two. Swirl them in me" (30). The stage directions read: "She turns 
her back to him. He lifts her skirt puts two into her vagina. Hands her one. They each take a bite and then begin to eat, in silence" (30). Michelle's efforts represent man's foul interference in nature to have a new generation with new features.

Michelle and Tenaka discuss the future of the new generation/creatures they wait for after changing their food and nutrition. Tenaka thinks that they "might dwell more completely in uncertainty" (31) which implies that these "entombed ones are full of untold possibilities-mysterious, fearing, hopeful, powerful" (Rosenthal para 4). Michelle, per contra, argues that the new (engineered) creatures "will live in peace within themselves," "will be more tender than we," and "will live long lives, running free" (31). She always defends her views strongly against Tenaka's. Michelle and Tenaka go further to show how the coming generation will be other than we:

Michelle: As long they're healthy, you know.

Tenaka: Smart and strong.

Michelle: As long as they're good.

Tenaka: It is what parents always have wished.

Michelle: Then why did it happens as it did?

Tenaka: Evolution got stuck.

Michelle: We are not parents, really.

Tenaka: Carriers, merely, nurturers, maybe.

Michelle: They won't be like... They will be...

Tenaka: Other than we. (31)

They see that the new generation will be so smarter and stronger in facing and resisting any natural disaster. Like Michelle and Tenaka, Eve and Opa have their own turn on the new creatures. While Eve asks about "the nature of the creatures who are inside" her seeing them as "miraculous," Opa is so aghast to reply: "Foolhardy. Outright dangerous" (32). He is afraid of that novel experiment of the two women: 
Opa: I am aghast, Evie.

Eve: Don't be, Opa.

Opa: To do this in your body, to your own self.

Eve: We had no choice.

Opa: To do it to others is unforgiveable. (32)

Opa is so worried about Eve: "I'm too worried about you" (33). Like Michelle with Tenaka, Eve defends her plan against Opa:

Opa: How could you think such a thing?

Eve: Because something had to be done.

Opa: That does not make it advisable, not doable.

Eve: What do you suggest? (33)

It is noteworthy to remark that Opa is opposing his granddaughter Eve refuting her plan of getting new creatures.

As a feminist, Eve defends what she and Michelle are doing, while the renowned public intellectual linguist and philosopher Opa, instead of backing his granddaughter's plan, is so "horrified" (34) that he refuses it root and branch. Justifying his attitude, he argues that the creatures the women will give birth to will be "mute, ignorant beasts." When Eve argues that "they are advancing life," Opa sarcastically completes: "By creating predators for Homo sapiens" (34). Eve justifies and defends her experiment by arguing that her own species will be good for nothing with the passage of time and hence she has to replace "Homo sapiens" with Newbies: "If any of our sort remain, we won't be able to take over again [sic]" (34). To Opa, what his granddaughter is actually doing is nothing more than "speciescide" (34). She further argues: "They'll have four legs, Opa, plus arms, hands. They'll be able to run like the wind. Nature's coming back" (35). In this way, the new species are well described as "hybrid creatures, human/non-human that will adapt and sustain themselves in the treacherous territory outside the Dome/Eden" (Rosenthal para 2). However, words like Opa's "speciescide" (34), Eve's "four legs" (35), "able to run like the 
wind" (35), "babies with hooves" (24), "sharp little hooves" (47), and the critic's "hybrid creatures, human/non-human" may all be significantly applicable to the virus annihilating the world and known as COVID-19. This justifies Eve's "Nature's coming back" metaphorically in this new form to avenge itself against man's transgressions against it — an idea having an echo in Malpede's next play, Troy Too.

As an ecofeminist, Eve asks her grandfather to generalize her and Michelle's experiment by telling everyone about it. The argument between the two reaches its climax when Opa (reminiscent of the firm Robert of Earthquakes) cynically asks Eve: "Are you sane, Eve? Are you any longer in your right mind?" and she (unlike Robert's weak voiceless daughter Freya) replies: "I'm not my mother, Opa. Don't fear" (36). The image is very significant and challenging. It metaphorically shows how the weak image of the voiceless woman (represented by Freya and her generation) in the past has turned stronger in the present by showing strong voices of women like Eve and Michelle. This may be a reason why Cindy Rosenthal argues: "Women are primarily power sources and healers in all of Malpede's work. They struggle mightily with male lovers, torturers, teachers, and family members" (para 2).

Despite Opa's rejection of the new creatures Eve fights for, the latter defends them zealously. She argues that they will know how to think about life, but Opa replies that they are mere animals:

Opa: It cannot come to good.

Eve: But it can. [...]

Opa: These things inside of you will be superior to us?

Eve: They will know how to think about life.

Opa: Think, Evie, please.

Eve: They will not feel separate, apart.

Opa: They are animals, at best. 
Eve: As are we, at best.

Opa: Biological organisms.

Eve: Of course, if we have succeeded, they will know more than we. (39)

Opa insists on calling the new creatures things: "You intend to birth these things" (39). Like Robert who has advised his daughter Freya to abort her child in Earthquakes, Opa advises his granddaughter Eve to "abort" (39) the things inside her. Unlike Freya who, reflecting radical ecofeminism, has been intimidated by her father's words, Eve, representing cultural ecofeminism, defends her situation against her grandfather: "Forget that, and not things, please. Newbies is how I think of them. They do bear your remarkable genes" (39). Thus, she not only refuses his calling them "things" by calling them "Newbies" but also refutes his advice to abort them by replying: "Forget that."

Unexpectedly, Eve thinks of getting rid of her pregnancy because of her worry about her own safety due to a ruin she has done herself: "You think I'm not scared? [...] I'd like to rip my belly" (39). Likely, Michelle, having got enough of her own pregnancy - a position she too has made for herself-storms at Tenaka claiming that he too should have been pregnant like her: "Why the fuck didn't you get yourself pregnant? [...] I am out-ofshape. Look at me, for god's sake. [sic] You can't even bear the sight of me anymore. I'm a freak" (40). This point shows how women have gradually giving up their natural role. But Tenaka, trying to give them confidence in themselves as birthers, tells Michelle: "You're otherwise occupied with the most important work. You are holding our children in your womb. I worship you, goddess" (41). Opa concludes this episode by arguing: "Human thought failed. We became incapable of knowing what we had to know" (44). Opa's argument is made clearer when the two women give birth to creatures with "sharp little hooves" (47). Moreover, 
the stage directions show that "Tenaka and Opa stand together in the clearing, each with a newbie at the breast. They are nursing" (48). The following lines show how nature is violated by turning roles upside down:

Tenaka: You move to the other breast now.

Opa: Right. (Pause as they both shift the newbies)

Tenaka: One is used up; the other fills up.

Opa: Neat.

Tenaka: Evolution usually is. (49)

This is how evolution is achieved by turning gender roles topsyturvy. Men have embarked upon women's roles of nursing newborns. This scene echoes Malpede's words to Jody StrimlingMuchow: "Ecofeminism isn't exclusive to women. My partner at Theatre Three Collaborative is a man, George Bartenieff. The cast in my plays is fifty-fifty, men and women" (para 16). However, Opa concludes this scene by asking Tenaka: "Tell me, Tenaka, just what you thought you were doing, when you violated nature so" (50). Opa is aware that they have toyed with nature.

Everything has turned upside down. Opa, refusing Eve and Michelle's methods, speaks for nature that has been much violated: "I wanted democratic solutions, not engineered creatures. I advocated mutual respect, individual liberty, public interest in the public good" (50). As a result of the engineered solutions suggested by both women, the gender roles have been reversed. Opa, "speaking to his newbies," says: "There, there, there it is. (to Tenaka) Lost the nipple" (50). This fact is stressed by Tenaka's "I've been nursing the newbies with Opa" (51). However, when Opa refers, for a while, to one of the newbies as having "bright" eyes and "a rather intelligent, inquisitive look" and Tenaka adds: "They will be wise" (51), the former does not allow himself to see any further advantages: "I won't go that far" (51), because this may go against Nature which he always stands for. At the same moment, 
Michelle appears to announce that "one of the newbies is sick" (52). Moreover, she realizes: "We've lost our minds. It's too much for us. We might call it off. Destroy them. Kill the two already born. Get rid of them. Let other animals eat them" (54). Michelle is so depressed that she regrets giving birth to such newbies: "They are not mine. They are creatures we made up. We owe them nothing. It was our fantasy, our mistaken idea; our invention is killing me" (55). But Eve, still defending her experiment of the newbies, is so horrified in giving birth to them that she cries: "Oh, please, please, kill me, let them live" (56). She further feels so pleased with them that she confesses:

Opa, look, what I've done. Hello, little ones. Oh, two, oh, how precious, how sweet, my ones. Oh, how lovely, oh, my darlings, my dearest darlingest dears. [...] Oh, my sweetest, sweet, sweet, sweetest in all the world, bestest, you put your mommy through something, but we did it. We did. What loves, what loves they are. I feel so good. I feel like... Let me get up. [...] I gave birth to the earth. [...] I gave birth...to a new race.

Thus, Eve is parenting the future while facing death. Despite their diverse attitudes towards the newbies, "the four characters in OTW give up their own lives to birth a new, wiser species" (Malpede, "Facebook Message to Sirwah," 8 Nov. 2021).

Despite all this, some of the newbies die. The two women have succeeded in giving birth to new creatures who are, unfortunately, unable to cope with nature. Michelle comments: "It's the worst, the absolute worst. Losing a child. [...] There is nothing worse than losing a child. But this, this has hit me so hard" (59). They have come to a blind alley. Eve, who has been always standing for the new experiment, comments:

We can't understand. Even with instruments, tests, the results would likely be inconclusive. We don't know 
everything. Why some live. Why we lived. Why some give up. We can't, you know that, as a physician, you more than anyone, we cannot control anything. We ought not to have tried. (60)

Only now does she realize that they cannot control anything and that they should not have indulged in such a strange abnormal experiment. The living newbies grow up rapidly but are nothing more than animals unable to cope with nature, Nature Opa has long lived defending: "I have loved nature" (61). Eve, Michelle, and Tenaka have come to nothing:

Eve: They were babies a minute ago. How did they grow up?

Tenaka: It was as it was.

Michelle: What is that supposed to mean?

Tenaka: I have no idea. (65)

Furthermore, the Newbies themselves are not aware of their identities nor of how to live. If some newbies die, some will live; but they will live as entirely ignorant creatures unaware of their entities. They are reminiscent of the zombies as depicted in Ling Ma's sci-fi novel Severance (2018): "One zombie can be easily killed, but a hundred zombies is another issue. Only amassed do they really pose a threat. This narrative, then, is not about any individual entity, per se, but about an abstract force: the force of the mob, of mob mentality" (Fan para 2). The newbies appeal to Opa: "What kind of creatures are we, Opa,/What kind of creatures shall we be?" (66). They ply Opa with queries:

Opa...tell us, please.

How do we live?

How do we live?

We are new and you are wise.

How do we survive? (66) 
These unanswered questions reflected in poetic lines by the play's finale stress two issues: first, the problem negotiated throughout the play is left unresolved; and second, poetry has been employed as one of the techniques used by the playwright to drive her idea home.

Again, the newbies' nature reflected throughout the play is strange since humans have interfered in it by changing their food and nutrition (31). They have been described as "fast on their feet," having "four legs," and "hands with opposable thumbs" (24). "They'll be able to run like the wind" (35). They are "Cuddly babies with hooves" (35) with "sharp little hooves" (47). They can be regarded as animals. This is the result of science as wrongly employed by the two females, Eve and Michelle. It is possible that such strange animals are the main reason for the viruses people suffer from everywhere. Malpede, connecting this with pandemics, comments:

In this county, there is great distrust of science when it reveals uncomfortable realities, then, of course, the zoonotic virus jumped from animals to humans...this has to do with human invasions of wildlife habitats and the ways in which we disrupt the lives of animals. There will be other pandemics as we continue to invade the living spaces of other species.

("Facebook Message to Sirwah," 28 July 2020)

Despite all this, "there would be a chance they would survive. [...] An animal would find them and raise them. A wolf-mother... (47). Thus, they do not know how to survive the dangers represented in nature since they are abnormal creatures. The dilemma is not confined to their ignorance of how to survive; it has to do with whether they will be safe on humanity or not, since they are hybrid creatures. This is reminiscent of "Project Blue," the bioengineered superflu in King's The Stand, that has leaked out of an American 
military base and led to chaos. It is also reminiscent of the zombies delineated in Ma's Severance and are the victims of the fatal "Shen Fever," "endlessly brushing their hair, applying and reapplying face lotion until their bodies disintegrate" (Hu para 1). If it is to be so, can one regard the newbies as the hybrid unknown entities paving the way for COVID-19 in Malpede's next play Troy Too?

Malpede's very short play Troy Too (2020), inspired by Euripides' The Trojan Women, stresses the pandemic represented by COVID-19 as an inevitable result of human's greed and transgression against nature. Its main characters are Goddess Profit, Goddess Plague, the Greek gods, Hecuba, Andromache, Kassandra, and Two Women Doctors. Malpede clarifies:

Profit represents capitalism that only cares for profit and Plague represents the degradation of the natural world, that allows for animal viruses to enter the human population. [...] They decide to punish the Greeks for violating Athena's temple in Troy, i.e. for going too far in raping and pillaging. ("Facebook Message to Sirwah," 7 June 2020) Representing capitalism, Profit reminds us of such people as Roy, Daniel, and Carter, the businessmen standing for capitalism in Bartlett's Earthquakes in London, who have been always after increasing the number of air flights to make a lot of money. Thus, just as the Greek gods decided "to 'punish' the Greeks for violating Athens's temple in Troy" and "for going too far in raping and pillaging," Profit and Plague decide to punish the contemporary human race for their interference in nature and going beyond their limits. More evidently, they punish the human race for their insatiability and greed by plaguing them with viruses. Thus, COVID-19, like the plagues in classical literature, is the divine retribution against those who have violated nature. Thus, Malpede has skillfully delineated her idea of "divine retribution" by 
employing Greek characters based on Euripides' The Trojan Women as a technique in her new piece.

The opening of the play is so significant: "Euripides insisted on giving voice to the victims: The magnitude of the crimes were such only those who suffered injustice at the hands of power and brute force retained the moral authority to bear witness" (1). The creator (or Euripides) gives voice to the victims. Whether the victims refer to the Trojan women who have been victimized and pillaged by the Greeks, or Nature that has been victimized by capitalists everywhere, or both, it is time for them-women and/or nature - now to have a louder voice for revenge because of the magnitude of the crimes committed against them. Women's revenge can be seen in their higher voice in the play and Nature's revenge can be seen in its anger shown in the coronavirus or COVID-19 with which the play is obsessed throughout. Moreover, transgression against women in the past can be regarded as transgression against nature in its wider scope because the former is part of the latter. Plague admits that it has been awakened from its "deep slumber" in its cave due to Profit's call to awaken human's gross missteps:

Above the stage, the Goddess Plague paces.

Plague: I woke from my deep slumber in my cave. The Goddess Profit called. She who clutches at the hearts of human creatures, driving them to heights unimaginable by every other living thing who clings to earth in all humility. Alone, increasingly isolate, the human person slaved to Profit knows no bounds.

The Goddess Profit enters

Plague: Why have you commanded me to come?

Profit: You speak well, Plague. Plus, I know you expected my summons here, alert in your deep sleep, yet dream-life awake to humans' gross missteps. 
Plague: Correct. (1)

Awakening Plague from its "deep sleep" is inevitable because humans' transgressions have reached their climax. Profit has summoned Plague to "sweep away the misconceptions plaguing those $[\ldots]$ gifted with the right of exploitation. They have gone too far" (1) in their transgressions and violations against Nature. Profit has taken upon itself to destroy those who have gone beyond their limits: "Profit bonds with no god but Greed. [...] Humankind's insatiable" (1). If insatiable people have no limits in searching for profit, Plague "too, [is] limitless, without compassion, wily and will stop nothing" (1).

As soon as "the gods depart," "Hecuba rises from the dust" to announce that her city has been stricken by Coronavirus. People are divided: some keep homes trembling in their beds and others, who have to survive, go out for their work into the stricken air to sicken and die. Thus, Hecuba rises to sigh for her stricken city:

This is my city, my city which once was great, but my city is no more. Stricken by pestilence and plague, its people cower and shake, they tremble in their beds, afraid to leave their homes. Only those who must survive by doing work others disdain dare go out into the pestilence stricken air there to sicken and die, convulse and choke on their own bile. (1-2)

The stage directions show how people are covered in plastic with masks. Even lovers cannot speak freely; they find difficulties in speaking to each other in masks: "Two LOVERS covered in plastic with masks and goggles, rise from the earth on separate sides of the stage. They struggle to speak to one another through their plastic sheeting" (2). All beings suffer from the symptoms of Coronavirus. Fish, a character in the play, is unable to breathe: "I cannot breathe. If I cannot neither can you. That is tragic irony. I'm just a fish. Get used to it" (3). 
Like Opa, who advised his granddaughter to abort her pregnancy due to critical environmental crises, Hecuba advises her daughter-in-law Andromache (who suffers from homelessness due to the virus-stricken atmosphere) to give her child up and go with any man wanting her and ready to pay:

Andromache (enters, her child strapped to her back): We are homeless, mother. Where do I go? Where sleep with my child at night.

Hecuba: You must give him up, take the work they offer, go with the man who wants you, who has money who can pay. [...] Necessity is harsh, my daughter. [...] Once we worked, nine, ten hours a day, cleaning up their messes, emptying their garbage, scrubbing their toilet bowls, but we survived. We went home at night to our own house, fed our own children, read to them, tucked them in. No longer. Our city, ours, has fallen. Its people become slaves to bitter circumstance. Plagues haunt us now.

In Andromache's case, people have become homeless because of the virus; they are so workless and penniless that they have become "slaves to bitter circumstances" (4). Again, like Eve, Andromache refuses to give up her child: "Never. I will carry my boy on my back forever. Never will I give up this child" (4). All this emphasizes that critical environmental disasters always entail poor economic milieus.

The chorus is split in two: "Chorus 1 wears MAGA hats and t-shirts" and "Chorus 2 wears masks and medical scrubs. They hold stethoscopes" (5). The two choruses mirror a facsimile of everyday life by expressing two divided opinions on the coronavirus:

Chorus 1: Praise, praise be our noble leaders who have presided over victory. Take off your masks, throw them away. Sing. Sing. We are free people. Free. 
Chorus 2: Mask yourself. Freedom is caring for others. Freedom is protecting our connections. Web of life. My mask prevents your death.

Chorus 1: [...] Real men don't wear masks. There is no disease, there is no contagion, the Dow Jones overcomes all illness. Eat, drink, spend, go to the casinos, the bars, racetracks, fireworks, open up.

Chorus 2: The science says we must stop community spread. Stay at home. Don't go out. Put on a mask. Protect those you do not know. Wash your hands. Honor the dead.

Chorus 1: There is no disease. You've been sold a load of bull. They will implant microchips. Their vaccine is poison. Anarchists. They will force it on you. They want complete control. Do not listen to the experts, what do they know.

Chorus 2: Look at the numbers. Listen to the science, the scientists. They tell us our world is burning up. They say the virus spreads invisibly in the air we breathe. They tell us sea level is rising. Storms becoming more intense. Food supply at risk. They tell us to stay safe.

Chorus 1: God will provide. If you believe their lies, you lack faith in the divine. You want to live in fear? Not me. I will be free. Made in the creator's image. Go where I please. Pass me a beer.

Chorus 2: We do God's work. If not us, who? If not now, when? We are God's hands. We work with one another for the greater good. Masked, at home, apart, we are One.

The above-quoted exchanges, written in everyday language, may be the most alerting ones throughout the text under discussion and 
the commonest words one hears about COVID-19 everywhere nowadays. They reflect two opinions in diabolic opposition with each other: the first representing the covidiot who pays no attention to the coronavirus and the second representing the science-oriented people who are cautious. Commenting on this split chorus, Malpede argues: "Yes, the split chorus represents that split- those who believe the reality and those who chose to believe Trump, Bolsinaro, Modi...etc" ("Facebook Message to Sirwah," 7 June 2020). She here refers to Brazil's Jair Bolsonaro and India's Narendra Modi who have much in common in their approach to COVID-19. As Jan D. Walter argues, "the two nations' case numbers accounted for more than half of all new infections globally. Despite such worrying statistics released by the World Health Organizaion, neither administration is prepared to impose a nationwide lockdown to help curb the COVID-19 pandemic" (para $1)$.

Kassandra's long speech to Hecuba about how "black children/Die on the street, their bodies left, while bystanders/Moan, or are shot in their beds" (6) reminds us of the Eritrean Tom in Bartlett's Earthquakes and the African Tenaka in Other Than We who talked about transgressions practiced against the environment and reflected on them. This image shows how the poor/Africans are the most affected people by environmental crises. Kassandra's speech swarms with words closely and directly addressing COVID-19: "A virus," "a pox," "bloated bodies diseased," "will struggle to breathe," "choke," "stalked by," "fate," "writhe," "'breathing system,'" "a cough," "a sniff," "a kiss" "without aid," "Nurses jump," "they have destroyed themselves," "consumed themselves to death," and "Their plagues they cause/Will destroy them utterly" (6-7). Kassandra's "Their plagues they cause" (7) reminds us of Robert's "this earthquake might be caused by us" (Bartlett 123). People are the very causes of their 
own plagues due to their violations of both environment and nature. This, however, has to do with the second wave of ecocriticism which explores the deeper destruction on the environment that is mainly caused by human action. Malpede argues: "The destruction we engage in will destroy not only us but the planet and all creatures. We must change our ways and find other heroic actions - birthing, nurturing, caring, these are the actions we now need to dramatize" ("Facebook Message to Sirwah." 8 Nov. 2021).

Moreover, Kassandra threatens to destroy the leader, (Trump) who has alleged that there is no virus nor contagion: "I go willing. Willingly to spit on him. Bring him down. The plague I bear will be his undoing. Let me go, to his demise, singing" (7). As a result, the reckless chorus, standing for Trump and his followers, hysterically reiterates:

I can't breathe. I can't breathe. I can't breathe. I can't breathe without delight. I can't breathe without scent, flowers, turmeric, sweat. I can't breathe without you at my side. My hand in yours. I can't breathe unless you take your knee off of my neck. [...] I can't breathe without love. [...] I can't breathe with virus in my lungs. I can't breathe unless I stand up. I can't breathe without help. Take my hand, heart, story. I can't stop.[...] I wanted to go home. I want to be at home. I want to walk free. I want to breathe. [...] Take your chemicals out of my air. Give me breath. Let me breathe. [...] We can't breathe. The CHORUS collapses.

Kassandra's "take your chemicals out of my air" shows how the air is so polluted with chemicals that no one can bear. However, when "Two Women Doctors rise from the dust" to help the dying chorus, they appear "exhausted. The marks from wearing masks for many hours show on their faces" (7). They confess they "have nothing" to do for the chorus (7). Thus, even the committed doctors are so 
exhausted due to the masks on their faces for long times that they cannot offer other virus-stricken people any help. The "women doctors" further signifies that women are more preoccupied with virus-stricken people than men.

The second chorus "came of [their] free will to live a crush next to others/[They] did not know" (8). This chorus too comes to finally warn people: "'This is your last chance' [...] we might live to do whatever we wished with whomever we chose" (9). The play, as Malpede has put it, "is left open at the end: perhaps 'free will' will save us. Perhaps, at the very final moment we shall act together in ways that will save, rather than destroy, the planet..." ("A Facebook Message to Sirwah," 7 Nov 2020). It is up to our free will to protect ourselves by keeping homes or to destroy ourselves by behaving as covidiots. In an article published in The Indypendent under the title "I've Survived the COVID Pandemic," Malpede emerges from lockdown to explain:

In April, when New York City was at the peak of COVID19, when sirens were screaming in the streets and emergency rooms were overloaded with very ill people, when the elderly were dying first and fast, my husband and I jointly vowed not to go to the hospital, certainly not to be intubated. (para 1)

Malpede expatiates on pointing out how her friends "have been careful and remain virus-free" (para 5). Hence, it is not strange that the playwright and her friends' talk- "about the disastrous Trump regime, the latest draconian pronouncements, the lies, assaults on science, on decency - leaves all of [them] infuriatingly sad" (para 6). Again, leaving her play open-ended indicates that the problem negotiated by it is left unresolved depending on man's free will! This open end is the playwright's technique for accentuating her idea. However, the language of the play has much derived from everyday language. This is what Malpede has emphasized in her 
final note on the play: "Much of the language in this play was found: on the street while participating in the protests, from an essential worker student and other medical professionals, by reading newspapers, listening to interviews, and reworked from memory" (10). In a message about the technique of both OTW and TT, Malpede argues: "In both plays I am looking for ways to make the unbearable truths visible and bearable (through language/poetry and character)" (Facebook Message to Sirwah," 8 Nov. 2021). Thus, by employing this language-shifting technique, she has succeeded in moving thematically from the Deluge in the cli-fi Other Than We to COVID-19 in this Troy Too.

In conclusion, the paper has pointed out how man's passive interference in nature to find solutions to the crisis of the Deluge in Other Than We has paved the way for the global phenomenon of COVID-19 in Troy Too. Trying to replace Homo sapiens with Newbies that will be other than we in facing natural disasters, OTW comes to a blind alley by giving birth to hybrid engineered creatures (with four legs and sharp little hooves) that will be able to run like the wind in bringing about the coronavirus in TT. A slice of life, Malpede's TT has negotiated COVID-19 and how opinions are divided into two parties: one believing in the coronavirus as annihilating our life and another disbelieving in it. The first party represents intellectual and aware people like Malpede and her friends, and the other Trump and his followers.

However, the paper has reached three findings. First, Malpede has moved thematically from the Deluge in OTW to COVID-19 in TT by employing techniques such as language shifting, the anachronistic representation of Euripides' personae, poetry, and open ends. The playwright has successfully based her $T T$ on everyday language, the language of interviews, newspapers, and that found on the street just to convince her readers of the realistic issue she tackles. Moreover, by utilizing Euripides' 
personae like Hecuba, Andromache, Kassandra, and the (Greek) gods - characters connected with plagues and fate, Malpede could really depict the coronavirus as a divine retribution. Her use of poetry at the end of $O T W$ when the newbies ply Opa with queries about their unknown identity and future has alerted readers' attention to the significance of the play's finale as a real impasse. Furthermore, leaving her two pieces $O T W$ and $T T$ open-ended has enabled Malpede's to drive her idea home by endorsing that the critical issue under discussion remains unresolved.

Second, it has been demonstrated how cultural ecofeminism surpassed radical ecofeminism in featuring women's roles not only in attempting a daring response to natural disasters but also in warning people against the gravity and immensity of pandemic diseases. In reply to radical ecofeminism, which has regarded both women and nature as equally dominated by the patriarchal society, both $O T W$ and $T T$ have successfully pointed out how women are more sensitive (than men) to the sanctity and degradation of the environment. In other words, in $O T W$, both women (Eve and Michelle) have taken upon themselves to find a solution to the environmental crisis of the Deluge and, in TT, Goddess Profit and Goddess Plague open the play to show that the plague/virus has appeared as a (divine) retribution against capitalists. Moreover, other women like Hecuba, Andromache, and Kassandra have appeared not only to attack leaders who, like Trump, have alleged there is no virus but also to warn people against the virus and its symptoms.

Third, the playwright's vision has crystalized in an admonishingly prophetic light: We must act together in ways that will save, rather than destroy, us as well as all creatures on the planet. The two natural disasters - the Deluge and COVID-19demarcated by the two plays are resulted from man's foul interference in and transgression against nature. The two women's 
attempt to solve the natural disaster of the Deluge by their experiment of engineered creatures has paved the way for the pandemic disease, COVID-19. Moreover, the splitting up of the chorus into two (one representing Trump and his followers who lie about the virus and the other representing Malpede and her friends who are cautious) has accentuated the playwright's message. In other words, Malpede has alerted our attention that the whole issue is up to our free will: We must change our ways and act together to save ourselves otherwise the destruction we engage in will annihilate not only us but also all creatures on the planet. 


\section{Works Cited}

Bader, Eleanor. "Hope Rises from Climate Disaster in Other Than We at La MaMa." The Indypendent. Nov 22, 2019. https://indypendent.org/2019/11/hope-rises-from-climatedisaster-in-other-than-we-at-la-mama/. Accessed 29 Aug. 2021.

Bartlett, Mike. Earthquakes in London. London: Bloomsbury Methuen Drama, 2010.

Bressler, Charles. Literary Criticism: An Introduction to Theory and Practice. Pearson, 2011.

Buell, Lawrence. The Future of Environmental Criticism: Environmental Crisis and Literary Imagination. Blackwell Publishing, 2005.

Camus, Albert. The Plague. New York: Vintage Books, 1991.

Chandra, N.D.R. and Nigamananda Das. Ecology, Myth and Mystery: Contemporary Poetry in English from Northeast India. New Delhi: Sarup \& Sons, 2007.

Fan, Jiyang. "Ling Ma's Severance Captures the Bleak, Fatalistic Mood of 2018." The New Yorker. Dec. 2018. https://www.newyorker.com/books/under-review/ling-maseverance-captures-the-bleak-fatalistic-mood-of-2018. Accessed 26 Oct. 2021.

Garrard, Greg. Ecocriticism: The New Critical Idiom. London: Routledge, 2004. Glotfelty, Cheryll and Harold Fromm, eds. The Ecocriticism Reader: Landmarks in Literary Ecology. London: The University of Georgia Press, 1996.

Haith, Chelsea. "Pandemics from Homer to Stephen King: What We Can Learn from Literary History." March 2020.

https://www.english.ox.ac.uk/article/pandemics-from-homer-tostephen-king. Accessed 28 Oct. 2021.

$\mathrm{Hu}$, Jane. "Severance Is the Novel of Our Current Moment—but Not for the Reasons You Think." The Ringer. Mar 18, 2020. https://www.theringer.com/2020/3/18/21184516/severancecoronavirus-book-ling-ma. Accessed 26 Oct. 2021.

King, Stephen. The Stand. Doubleday, 1974.

Ma, Ling. Severance. Picador, 2018.

Malpede, Karen. "Facebook Message to Khaled Sirwah," 7 June 2020.

---. "Facebook Message to Khaled Sirwah," 11 June 2020.

---. "Facebook Message to Khaled Sirwah," 28 July 2020.

---. "Facebook Message to Khaled Sirwah," 08 Nov. 2021.

---. "I've Survived the COVID Pandemic. So Far. Now What?" The Indypendent. Issue 257. Jul 17, 2020. 
https://indypendent.org/2020/07/ive-survived-the-covid-

pandemic-so-far-now-what / Accessed 20 Aug. 2021.

---. Other Than We. North Carolina: Laertes Press, 2019.

---. "Troy Too." Oct 1, 2020. http://thetypescript.com/troy-too-bykaren-malpede/ Accessed 30 Sep. 2021.

Meyer, Deon. Fever. Grove Press, 2016.

Miles, Kathryn. "Ecofeminism: Sociology and Environmentalism." https://www.britannica.com/topic/ecofeminism. 17/10/2021.

Mishra, Sandip and Karanjee Subhas Bidyabhaban (2016). "Ecocriticism: A Study of Environmental Issues in Literature." BRICS Journal of Educational Research | October-December 2016. Vol. 6. Issue 4. https://www.researchgate.net/publication/318350741 Ecocriticis m A Study of Environmental Issues in Literature.20/09/2021.

Murray, A.T. Homer: The Iliad, Books I-XII, Harvard University Press, 1999. Rosenthal, Cindy. "Who? Whoo! Other Than We: Karen Malpede's Latest Ecofeminist Play at La Mama." The Theatre Times. 2019. https://thetheatretimes.com/who-whoo-other-than-wekarenmalpedes-latest-eco-feminist-play-at-la-mama/Acceseed 14 Oct. 2021.

Shinde, Shobha Padmakar. "Ecocriticism: Concepts and Implications." International Multidisciplinary Research Journal. Vol. IV. Issue IV: July 2016. Pp. 107-114.

Sophocles. Oedipus the King. Trans. David Grene. Chicago: The University of Chicago Press, 1991.

Stock, Jennifer. "Studying Pandemic Literature" Contemporary Literary Criticism. Vol. 483. July 26, 2021. https://blog.gale.com/studyingpandemic-literature/

Stoker, Bram. Dracula. Dover, 2000.

Strimling-Muchow, Jody. "The World is Wrong-side Out: A Conversation with Playwright Karen Malpede." Sep. 11. 2021. https://getlitbeacon.com/2019/05/29/the-world-is-wrongside-out-a-conversation-with-playwright-karen-malpede/. Accessed 9 Nov. 2021.

Walter, Jan D. "Modi and Bolsonaro: 2 Populist Leaders Approach to COVID-19." May 2021. https://www.dw.com/en/modi-andbolsonaro-2-populist-leaders-approach-to-covid-19/a-57444629. Accessed 31 Sep. 2021. 
استكشاف الانتقال الدرامي من "الطوفان" إلى "كوفيد 9 ا": دراسة حالة

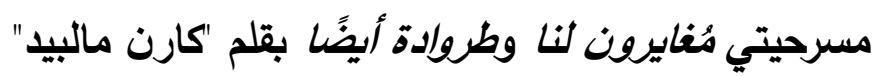

\section{مُلخص}

يبرهن البحث الحالي على وجود أحد أشكال الانتقال الدرامي من ظاهرة "الطوفان" الطبيعية إلى ظاهرة "كوفيد 9 ا" العالمية. وللمُضي قُدمًا نحو تحقيق هذا الهدف، فقد اعتمد البحث على منهج نقدي بيئي يتتاول نصين مسرحيين بقلم "كارن مالبيد": مغايرون

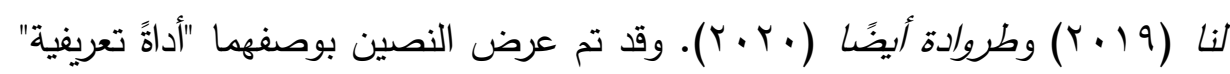
درامية تكثف آثار تعدي الإنسان على الطبيعة من خلال تفاقم الكارثة البيئية المتطورة من "الطوفان" في النص الأول إلى "كوفيد 9 ا" في النص الأخير • وقد توصل البحث

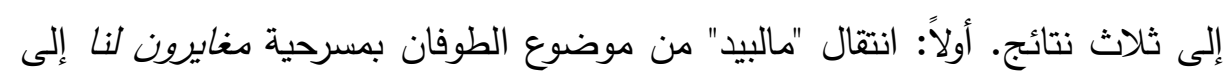

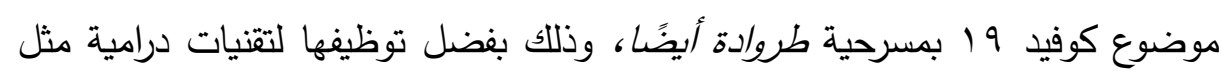
النقلة اللُغوية واستخدام شخصيات "يوريبيدس" التاريخية والثعر والنهايات المفتوحة. ثانيًا: تجلت سيادة النسوية الثقافية على نظيرتها الراديكالية في إبراز دور المرأة ليس فقط في محاولتها طرح أجوبة جريئة في تناول موضوع كوارث الطبيعة ولكن أيضًا في تحذيرها البشر من خطورة وفداحة الأمراض الوبائية. ثالثًا: لقد تبلورت رؤية الكاتبة التتويرية على هلى هورل

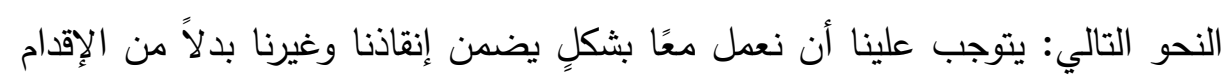
على خطوة من شأنها تدميرالأخضر واليابس. الكلمات المفتاحية: كوفيد 9 1، الطوفان، النقد البيئي، النسوية البيئية، البيئة، البثر ولئر العاديين، الطبيعة، المُستحدثون، الوباء، طروادة 